\title{
GUIDELINES FOR CONTRIBUTORS
}

Business History Review seeks articles drawn from rigorous primary research that address major debates and offer comparative perspectives. We consider the history of entrepreneurs, firms, and business systems, and the subjects of innovation, globalization, and regulation. We are also interested in the relation of businesses to political regimes and the environment.

Manuscripts are considered for publication on the understanding that they are not currently under consideration elsewhere and that the material-in substance as well as form-has not been previously published.

Manuscripts should be submitted by e-mail to bhr@hbs.edu.

Authors of accepted manuscripts will receive a copy of the issue in which their article appears and a pdf file.

We encourage BHR authors to make their abstracts available on SSRN after the publication of their articles.

\section{MANUSCRIPT PREPARATION}

Authors must remember not to identify themselves in the body of the manuscript; specifically, references to their own work in the text should be in the third person, and citations should be written without possessive pronouns-not "See my ..."

We use the 16th edition of The Chicago Manual of Style (2010) and spell and hyphenate words according to Merriam-Webster's Collegiate Dictionary.

Send a bio of three to four sentences, stating affiliation and recent publications.

Be sure to include an abstract of no more than 100 words outlining the main point(s) of the paper and placing the article in context. Subheads should be used to divide the manuscript into three or four sections (or more, depending on length).

Articles should not be more than 10,000 words in length, including footnotes.

Each table and figure must be accompanied by a complete source.

When submitting figures, make sure images are in black and white and also include the data files. Tables should be prepared in a Word format to facilitate in-house editing.

Authors are responsible for obtaining all illustrative materials and permissions for reproduction, and for writing captions.

The journal encourages authors to use gender-neutral prose in all cases where it is not anachronistic to do so; male nouns and pronouns should not be used to refer to people of both sexes.

We use the day-month-year form for dates in citations, as 11 February 2007.

Double quotation marks should be used for journal article titles and direct quotation; single quotation marks are used for quoted material inside quotations.

\section{SAMPLE CITATIONS}

BOOK: Thomas K. McCraw, Prophet of Innovation: Joseph Schumpeter and Creative Destruction (Cambridge, Mass., 2007), 205-21.

JOURNAL: Naomi R. Lamoreaux, "Scylla or Charybdis? Historical Reflections on Two Basic Problems of Corporate Governance," Business History Review 83 (Spring 2009): 9-34.

Note that we do not include the publisher in book citations. We do not use loc. cit., op. cit., or idem., but ibid. (not italicized) may be used.

\section{EDITORIAL OFFICE}

Business History Review

Harvard Business School

Soldiers Field

Boston, MA 02163, USA

Tel.: +1 6174951003

Fax: +16174950594

E-mail: bhr@hbs.edu

www.hbs.edu/bhr

\section{BUSINESS OFFICE}

Cambridge University Press

The Edinburgh Building

Shaftesbury Road

Cambridge CB2 8RU, UK

Tel.: +441223326498

Fax: +44 1223325801

E-mail: journals@cambridge.org

www.journals.cambridge.org/bhr 


\section{BUSINESS HISTORY REVIEW}

Howell Harris, Coping with Competition: Cooperation and Collusion in the US Stove Industry, c.1870-1930

Per H. Hansen, Business History: A Cultural and Narrative Approach

Maria del Carmen Collado, Entrepreneurs and Their Businesses during the Mexican Revolution

Chibuike U. Uche, British Government, British Businesses, and the Indigenization Exercise in Post-Independence Nigeria

Yongdo Kim, Interfirm Cooperation in Japan's Integrated Circuit Industry, 1960s-1970s

ReVIEw Essay

William R. Childs reviews What's Good for Business: Business and American Politics since World War II, edited by Kim Phillips-Fein and Julian E. Zelizer 